\title{
Maranhão earthquake of January 3, 2018 - a new GT5 event in the aseismic region of the Brazilian phanerozoic Parnaiba Basin
}

Lucas Barros ${ }^{1}$, Marcelo Rocha ${ }^{1}$, Marcelo Assumpção ${ }^{2}$, George Sand ${ }^{1}$, Brígida Bowen ${ }^{1}$ and Juraci Carvalho ${ }^{1}$.

1- Seismological Observatory - University of Brasília

2- Seismological Center - University of São Paulo

\section{Copyright 2018, SBGf - Sociedade Brasileira de Geofísica}

Este texto foi preparado para a apresentação no VIII Simpósio Brasileiro de Geofísica, Salinópolis, 18 a 20 de setembro de 2018. Seu conteúdo foi revisado pelo Comitê Técnico do VIII SimBGf, mas não necessariamente representa a opinião da SBGf ou de seus associados. É proibida a reprodução total ou parcial deste material para propósitos comerciais sem prévia autorização da SBGf.

\begin{abstract}
Here it is presented the preliminary results of study, with local network, of the aftershock activity occurred in the aseismic region of Vargem Grande, Maranhão state, after a $4.6 \mathrm{mb}$ mainshock on January 3,2017 . The focal mechanism solution indicates a strike slip fault with compression parallel to the cost line in agreement with previous studies. The aftershock activity was very intense in the begin fading to just few events after couple of days and the aftershock network only registered 60 events within two months. Hypocentral location of 10 events showed a possible trace of the fault in agreement with focal mechanism solution. The relocation of the main event with station correction and fixed depth was located within the aftershock cluster with accuracy of a GT5 event requirements.
\end{abstract}

\section{Introduction}

On January 3, 2017, an earthquake with magnitude 4.6 $\mathrm{mb}$ occurred on the border of the Parnaíba Basin, a completely aseismic area near the northern coast of Brazil (Fig. 1). This event was recorded by several stations of the Brazilian Seismographic Network (RSBR), composed of broadband stations $(50 \mathrm{~Hz}$ to $120 \mathrm{~s})$ with relatively low noise (Bianchi et al. 2015). Despite the large distances between most of the RSBR stations, a wellconstrained strike-slip focal mechanism was obtained with coast-parallel $P$ axis and coast-perpendicular T axis (Dias et al., 2017). The base for the Dias et al. (2018) analysis was the data from the closest RSBR station (ROSB), located $40 \mathrm{~km}$ away from the epicenter. Such detailed analysis of the backazimuths and S-P differences of 20 aftershocks allowed the determination of the rupture size of the main shock to be around $2 \mathrm{~km}$ and the identification of the fault plane to be the NNW-SSE trending nodal plane, consistent with moment-tensor solution by regional waveform inversion.

A few days after the mainshock, a local seismic network was deployed, initially with two stations and one month later three more stations composing a network of six stations with an aperture of about $50 \mathrm{~km}$. The aim of this work is to present the analysis of the data gathered by the local network showing new results in addition the work of the Dias et al. (2018) that was not possible with the regional stations, like a better description of the fault trace, clarify event depth using data from the local network and catalog Volta Grande earthquake as a GT event.

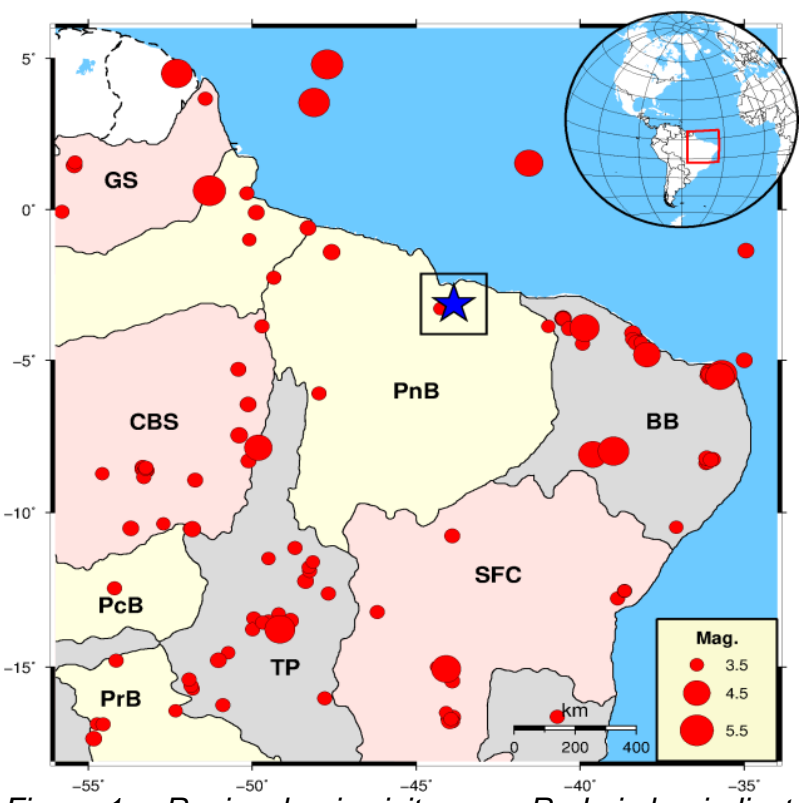

Figure 1 - Regional seismicity map. Red circles indicate the seismic events from the Brazilian Seismic Bulletin and the magnitudes as in the legend. The geological provinces are indicated by different colors: dark pink Precambrian regions - São Francisco craton (SFC), Central Brazil Shield (CBS) and Guiana Shield (GS); light yellow - Phanerozoic regions, Parecis Basin (PcB), Paraná Basin (PrB), Amazon Basin (AmB) and Parnaiba Basin (PnB); mobile shield - light grey, Borborema Province (BB) and Tocantins Province (TP). The blue star denotes the main shock epicenter. Black square highlight Figure 2.

\section{Geological and geophysical setting}

The study area is localized in the northern part of the Parnaiba Basin (Figure 1). It is an intracratonic Phanerozoic basin with a sedimentary column up to $3,400 \mathrm{~m}$ thick deposited over a Pre-Cambrian crystalline basement. However, on its north border the sediment package has a thickness of about $500 \mathrm{~m}$. This is clearly identified analyzing the seismic phase conversion on the interface sediment-basement ( $P$ to $S-P s$, and $S$ to $P$, $\mathrm{Sp})$. The sediments correspond to transgressiveregressive cycles with continental, lagoon, transitional and marine origin (Soares et al., 1978 and Góes et al., 
1993). According to Góes et al. (1993), the evolution of the Parnaiba Basin started with the thermal contraction that occurred at the end of the Brasiliano Cycle and induced the initial depression of the basin. Later, the initial stages of the Gondwana fragmentation generated the reactivation of faults and an intrusive magmatism. The weight of the vulcano-sedimentary load that was installed on the crust allowed the deposition of clastic sediments. It is a very aseismic region in the Northern Brazil with only one event with lower magnitude.

\section{Data and analysis}

A local seismic network, with 5 stations, was deployed in the region of Volta Grande - MA to better study the aftershock activity of the January 3, 2017 mainshock, magnitude $4.6 \mathrm{mb}$ and intensity $\mathrm{VI}(\mathrm{MM})$. This event was registered by 21 stations of the Brazilian Seismographic Network (RSBR) and the nearest station (ROSB) is located about $40 \mathrm{~km}$ away. The local network was deployed in two stages: from January 12-15, the stations VGMA1, VGMA2 and VGM4 and from February 8 - 12, the stations VGM5 and VGM6 (Fig. 2).

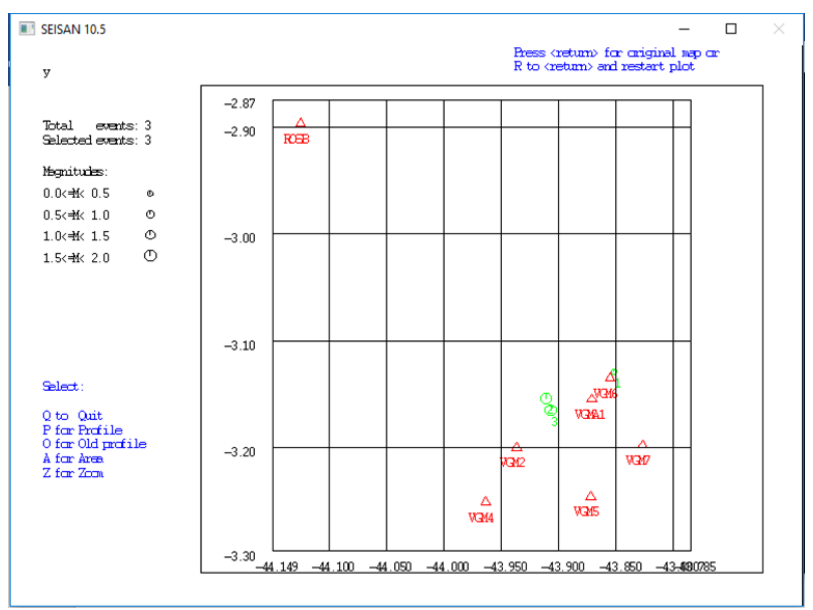

Figure 2 - Local seismic network. Green circles denote the two best located events (numbers 2 and 3) with data from five stations and the main shock (number 1) located with ROSB station and depth fixed at $12 \mathrm{~km}$.

The after-shock activity was expressive at the beginning and suddenly almost died few days after. Figure 3 shows six hours of data in the ROSB station around the main shock origin time. As we can see, more than 50 events were detected in this lapse of time. However, during February and March the local network detected only 60 weak events. This set of events is the base of our analysis in this work.

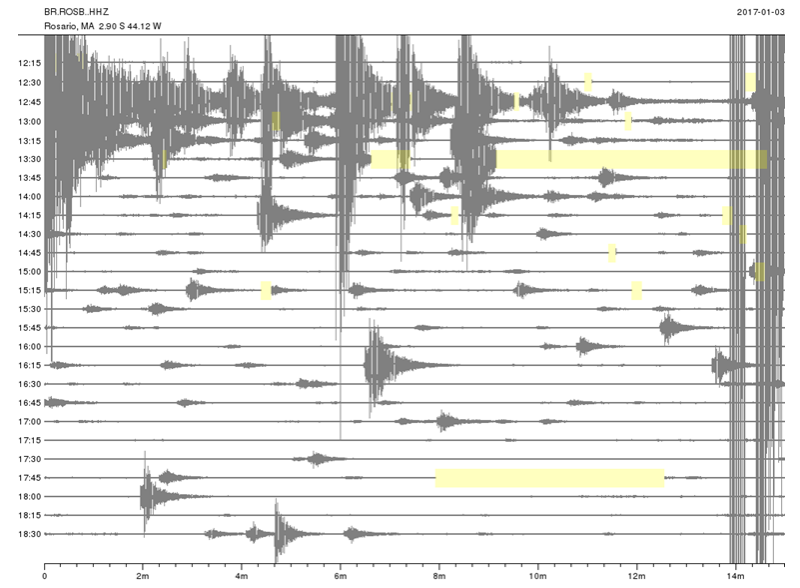

Figure 3 - Seismic activity in the first six hours after the Maranhão main shock occurrence (blue arrow) detected by ROSB station.

\section{Velocity Model}

A velocity model was determined by a Wadati diagram with data from 10 aftershocks detected by at least three stations up to five. The best adjustment was obtained for $\mathrm{Vp} / \mathrm{Vs}=1.73$.

Following the methodology developed by Barros and Assumpção (2011) in order to determine the sediment thickness in the Phanerozoic Parecis Basin, Dias et al. (2018) found that the Phanerozoic Parnaiba Basin presents in the epicentral area, a sedimentary package with a thickness of $500 \mathrm{~m}$. For the sediments, we adopted a $\mathrm{Vp}$ of $4,0 \mathrm{~km} / \mathrm{s}$ and for the second layer, $10 \mathrm{~km}$ thick, the velocity of $6.0 \mathrm{~km} / \mathrm{s}$. These two layers are important for the aftershock event locations as the local network has an aperture of about $50 \mathrm{~km}$.

\section{After-shock hypocentral location}

A set of ten events was selected for analysis (Table 1). Figure 4 shows the correspondent epicenters. The events are disposed in two clusters, not well defined, both at a NW-SE trend with depth changing from 10 to $18 \mathrm{~km}$. These depths are not well constrained due to the data quality. However, two events detected by five stations constrained the depth at $18 \mathrm{~km}$. 


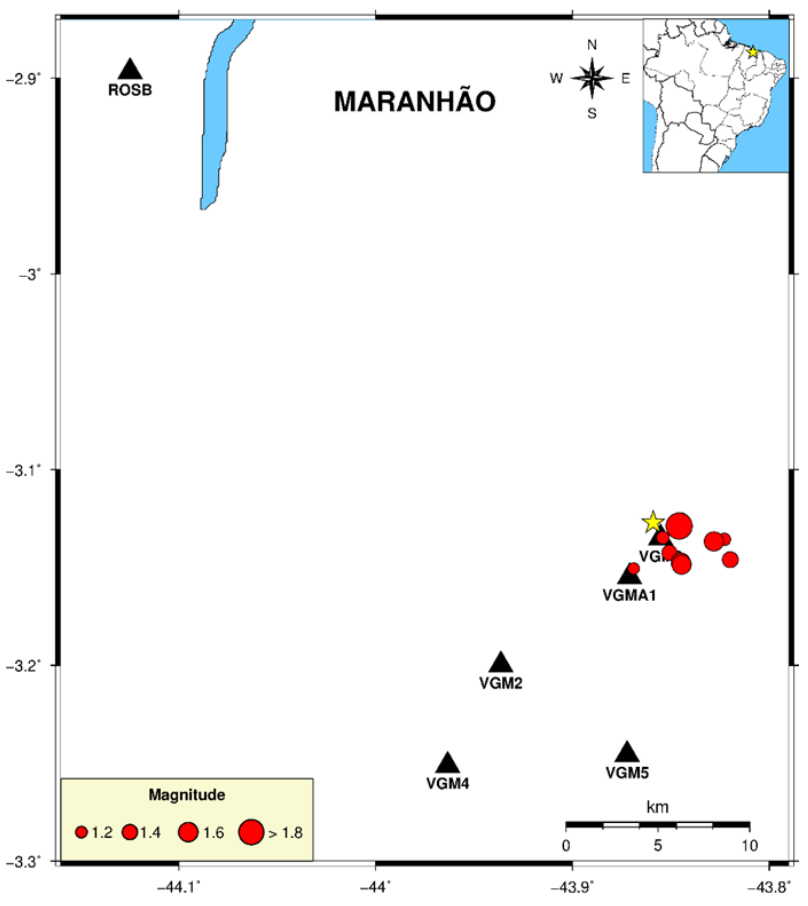

Figure 4 - Epicentral map of a set of ten events located with data from three stations. The yellow star denotes the main epicenter.

Table 1 - Seismic source parameters of the ten aftershocks and the main event (1) in Figure 4.

\begin{tabular}{|llllccccccc|}
\hline Nu. & Date & Origin & Lat & Long & Depth & Mag & No & Gap & Dmin & Rms \\
\hline 1 & $2017 / 01 / 03$ & $12: 43: 46.49$ & 3.1267 & 43.8587 & & 4.6 & 3 & 360 & 39.0 & 0.00 \\
& & & & & $12.0^{*}$ & & & & & \\
\hline 2 & $2017 / 01 / 19$ & $07: 16: 22.68$ & 3.1505 & 43.8688 & 15.0 & 1.2 & 6 & 269 & 9.3 & 0.04 \\
3 & $2017 / 01 / 19$ & $07: 56: 28.83$ & 3.1425 & 43.8507 & 14.2 & 1.4 & 6 & 274 & 11.4 & 0.04 \\
4 & $2017 / 01 / 19$ & $23: 02: 20.42$ & 3.1348 & 43.8540 & 10.1 & 1.3 & 6 & 272 & 11.6 & 0.02 \\
5 & $2017 / 01 / 22$ & $14: 40: 52.14$ & 3.1475 & 43.8450 & 13.0 & 1.6 & 6 & 277 & 11.7 & 0.03 \\
6 & $2017 / 01 / 26$ & $16: 12: 12.97$ & 3.1288 & 43.8458 & 9.50 & 1.9 & 6 & 274 & 12.8 & 0.05 \\
7 & $2017 / 01 / 27$ & $11: 31: 22.89$ & 3.1357 & 43.8228 & 10.4 & 1.3 & 6 & 283 & 14.5 & 0.02 \\
8 & $2017 / 01 / 27$ & $11: 31: 22.96$ & 3.1485 & 43.8445 & 13.4 & 1.6 & 6 & 278 & 11.7 & 0.03 \\
9 & $2017 / 02 / 01$ & $20: 12: 36.02$ & 3.1367 & 43.8282 & 11.2 & 1.6 & 6 & 281 & 13.9 & 0.03 \\
10 & $2017 / 02 / 01$ & $22: 14: 26.27$ & 3.1272 & 43.8455 & 11.1 & 1.7 & 6 & 274 & 12.9 & 0.05 \\
11 & $2017 / 02 / 02$ & $07: 15: 10.33$ & 3.1460 & 43.8198 & 12.4 & 1.5 & 6 & 285 & 14.3 & 0.09 \\
\hline
\end{tabular}

\section{Main shock location}

The Maranhão January 3 earthquake was detected very well by 21 stations of the Brazilian Seismographic Network (RSBR) located up to 20 degrees away. The closest station, ROSB, is located in Rosario - MA, $40 \mathrm{~km}$ away.

Due to the long epicentral distances of the other stations we decided to locate the main event using data only from the ROSB station. We used data from the two best registered events detected by the same five stations, including ROSB, to determine the depth of the seismogenic fault and the station correction for ROSB. The depth was gotten using, besides data of the two events, detected by five stations, additionally we used the difference of S-P time in the VGMA1 station. The aftershocks mean depth was adopted to fix the main shock depth. Station correction for ROSB was determined locating the events using zero weight in ROSB. This weight was applied to correct heterogeneities in the ray path not compensated by the 1D model.

\section{Focal Mechanism determination}

A confident focal mechanism determination was possible using two events detected simultaneously by five stations with 10 clear polarities and seven polarities from the main shock (Figure 5).

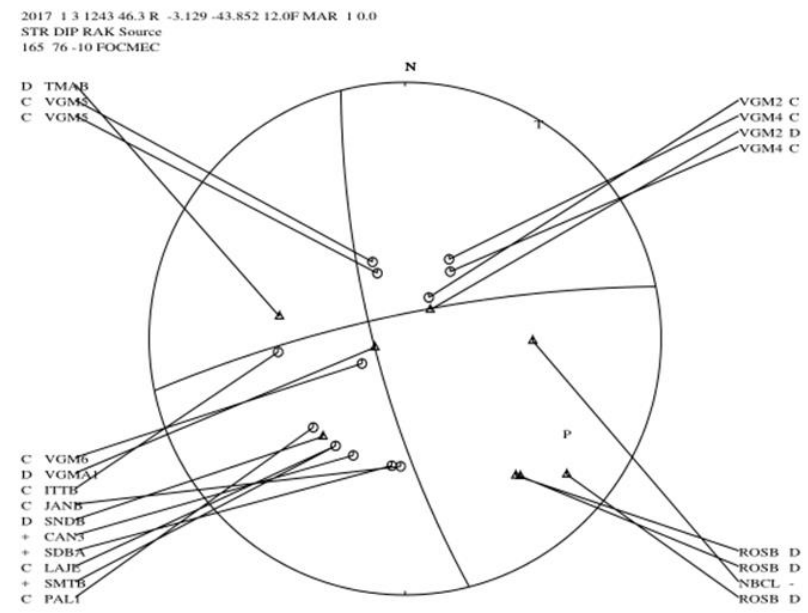

Figure 5 - Focal mechanism solution for a set of three events: two aftershocks detected by five stations (10 polarities) and seven well constrained polarities of the main shock, one wrong polarity. 


\section{Composite Focal Mechanism}

A second solution was attempted using a set of twelve aftershocks with 22 polarities and allowing two misfits. The results are basically the same above (Figure 6).

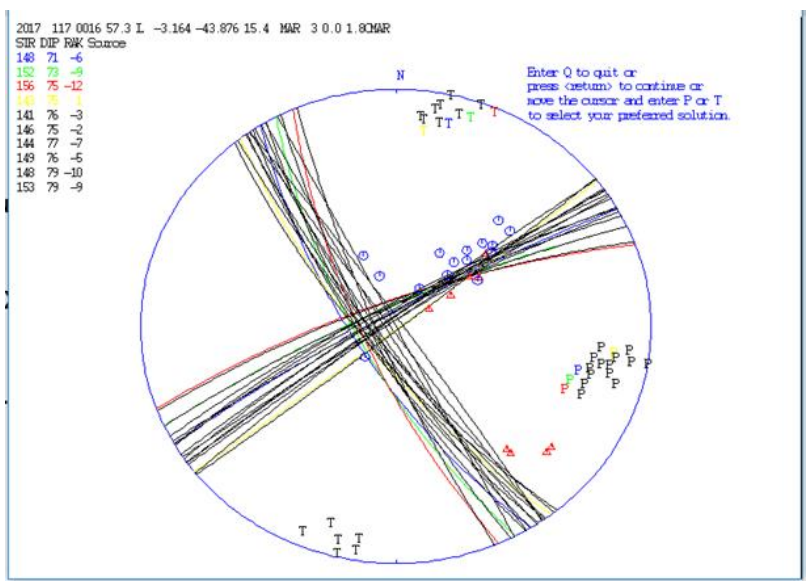

Figure 6 - Focal mechanism for a set of 12 events, 22 polarities allowing two misfits

\section{Macroseismic Survey}

A macroseismic survey was done during the aftershock field campaign, in newspapers and complemented by telephone interviews, comprising up to 70 points of observation. The results are presented in Figure 7.

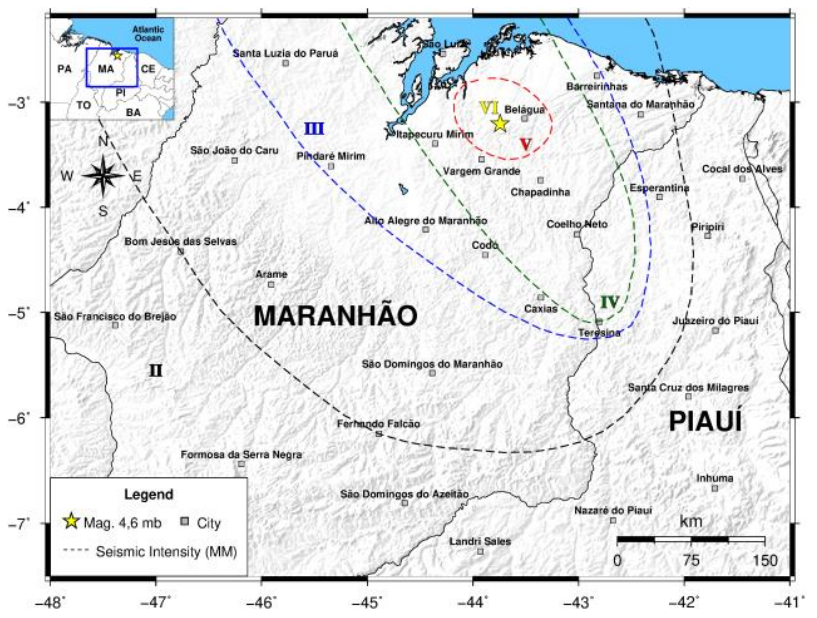

Figure 7 - Macroseismic map for Vargem Grande - MA Earthquake of January 3, 2017.

\section{Historical event}

Interviewing people from the various local communities, it was reported that this was not the first time that the earth trembled in the region. In almost all the communities, we found people who felt this historic tremor and with similar intensity of the January 3, 2017 earthquake. Despite the fact that many people perceived both earthquakes with similar intensities, we noticed that the historical earthquake had a slightly lower intensity, perhaps a degree less, i.e., intensity $V(\mathrm{MM})$. People remember the time of day, in the morning, between six and eight o'clock am, but they do not remember the year. According to reports, the earthquake happened between 42 and 45 years ago. In several communities where we found older people living, they informed us about this occurrence. Therefore, it is conclusive that the event happened and was perceived with an intensity $\mathrm{V}$, considering the current with maximum intensity of $\mathrm{VI}(\mathrm{MM})$.

\section{Discussion and conclusion}

The preliminary results of hypocentral location and composite focal mechanisms determination was presented. A set of events selected for analysis provided two FM solutions, first one with a set of 10 events detected by same tree stations and second two best aftershock polarities grouped with 7 clear polarities from the main shock. Both calculations presented same results: and strike slip fault with compression NW-SE parallel to the cost line and in agreement with the expected regional stress (Dias et al., 2017). Despite of the calculated depths from the events relocations indicated a range of 10 to $15 \mathrm{~km}$, the hypocentral location of the two best events (Fig. 8) detected by the same 5 stations, indicates that the depth could be around $18 \mathrm{~km}$.

The main shock relocation was done with the help of the two best aftershocks using time correction at ROSB station and the location laid within the aftershock cluster. In conclusion, we presented here preliminary results of a work that are in progress.
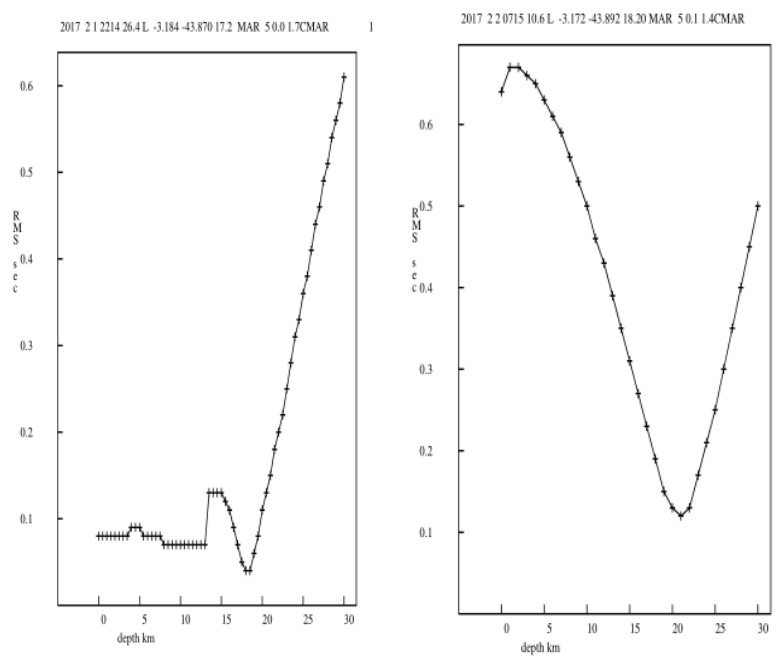

Figure 8 - Graphical representation of the residual RMS and depth calculate with the two events recorded by 5 stations. The minimum residual was for a depth around $18 \mathrm{~km}$. 


\section{References}

Barros, L.V. \& Assumpção, M., 2011. Basement depths in the Parecis Basin (Amazon) with receiver functions from small local earthquakes in the Porto dos Gaúchos Seismic Zone, J. South Am. Earth Sci., 32, 142-151.

Bianchi, M. et al. 2015. The Brazilian Seismographic Network: Historical overview and current status, Summary. Bull. Int. Seismol. Cent., 49(1-6), 70-90, http://www.isc.ac.uk/iscbulletin/summary/.

Dias, F.L., Assumpção, M., Bianchi, M.B., Barros, L.V. and Carvalho, J.M., 2018. The intraplate Maranhão earthquake of 2017 January 3, northern Brazil: evidence for uniform regional stresses along the Brazilian equatorial margin, Geophys. J. Int. (2018) 213, 387-396.

GÓES, A.M.O.; TRAVASSOS, W.A.; NUNES, K.C. Projeto Parnaíba -Reavaliação da bacia e perspectivas exploratórias. Belém: Petrobras, 1993, v. 1.

SOARES, P.C.; LANDIM, P.M.B.; FÚLFARO, V.J. Tectonic cycles and sedimentary sequences in the Brazilian intracratonic basins. Bulletin Geological Society of America, n. 89, p. 181-191. 1978. 